\title{
ОБ'ЄКТИВНІСТЬ ЯК ПРИНЦИП ОПЕРАТИВНО-РОЗШУКОВОЇ ДІЯЛЬНОСТІ В РОБОТІ ПІДРОЗДІЛІВ КРИМІНАЛЬНОї ПОЛІЦІї
}

Стащак А. Ю.

Метою статmі є визначення поняття «принцип об'єктивності під час оперативно-розшукової діяльності підрозділів кримінальної поліції». Автором робиться спроба визначення змісту та характеризуючих ознак принципу об'єктивності під час оперативно-розшукової діяльності підрозділів кримінальної поліції. Аналізуються надані раніше фахівцями у сфері оперативно-розшукової діяльності, адміністративного права, економіки, філософії та історичних наук визначення поняття «об'єктивність». Констатується, що принцип об'єктивності під час оперативно-розшукової діяльності підрозділами кримінальної поліції полягає в повсякденному використанні означеним суб'єктом певних критеріїв, які дадуть змогу встановити реальні обставини підготовки чи вчинення злочину, осіб, котрі вчиняють протиправну діяльність, виявити відомості, що становлять інтерес для кримінального провадження. В економічних науках принцип об'єктивності полягає в адекватному описі вихідних параметрів працівника. Це головний принцип оцінки, він зумовлює обов'язковість використання наукових методів, які дають максимально можливу об'єктивну оцінку. Принципи своєчасної комплексності та результативності вимагають того, щоб вихідні параметри і показники (оцінки), що використовуються при вирішенні того чи іншого кадрового завдання, були своєчасно і в повному обсязі представлені й обов'язково використані. Зроблено висновок, що об'єктивність у сфері оперативно-розшукової діяльності полягає в сукупності таких критеріїв, як: неупередженість; не врахування власних уподобань, думок, віросповідання або інших факторів конкретного працівника під час здійснення оперативно-розшуковоі діяльності щодо об'єктів оперативної розробки, об'єктів перекриття, негласного апарату тощо як основного критерію прийняття рішення; незалежність у прийнятті рішень від політико-соціального й економічного становища як власного, так і осіб - об'єктів контролю; керування під час здійснення оперативно-розшукової діяльності виключно нормами закону; співвідношення фактичних ознак злочину в діях особи та наказу керівництва щодо притягнення такої особи до кримінальної відповідальності.

Ключові слова: об'єктивність, принцип, оперативно-розшукова діяльність, підрозділи кримінальної поліції.

Целью статьи является определение понятия «принцип объективности в ходе оперативно-розыскной деятельности подразделений криминальной полиции». Автором делается попытка определения содержания и характеризующих признаков принципа объективности в ходе оперативно-розыскной деятельности подразделений криминальной полиции. Анализируются предоставленные ранее специ алистами в сфере оперативно-розыскной деятельности, административного права, экономики, философии и исторических наук определения понятия «объективность". Констатируется, что принцип объективности в ходе оперативно-розыскной деятельности подразделениями криминальной полиции заключается в повседневном использовании указанным субъектом определенных критериев,

Стащак А. Ю., 2019 в конечном виде предоставляющих возможность установить реальные обстоятельства подготовки или совершения преступления, лиц, совершающих противоправную деятельность, выявить сведения, представляющие интерес для уголовного производства. В экономических науках принцип объективности заключается в адекватном описании выходных параметров работника. Это главный принцип оценки, он обусловливает обязательность использования научных методов, дающих максимально возможную объективную оценку. Принципы своевременной комплексности и результативности требуют того, чтобы выходные параметры и показатели (оценки), используемые при решении той или иной кадровой задачи, были своевременно и в полном объеме представлены и обязательно использованы. Сделан вывод, что объективность в сфере оперативно-розыскной деятельности заключается в совокупности следующих критериев: беспристрастности; не учете собственных увлечений, мыслей, вероисповедания или других факторов конкретного работника при осуществлении оперативно-розыскной деятельности в отношении объектов оперативной разработки, объектов перекрытия, негласного annapama и др. качеств основного критерия принятия решения; независимости в принятии решений om политико-социального и экономического положения как собственного, так и лиц - объектов контроля; управления при осуществлении оперативно-розыскной деятельности исключительно нормами закона; соотношения фактических признаков преступления в действиях лица по приказу руководства по привлечению такого лица к уголовной ответственности.

Ключевые слова: объективность, принцип, оперативно-розыскная деятельность, подразделения криминальной полиции.

The purpose of the article is to define the notion of "the principle of objectivity in the operational and search activities of criminal police units". The author makes an attempt to determine the content and characterizing signs of the principle of objectivity during the operational-search activities of criminal police units. It analyzes previously provided by experts in the field of operational-search activities, administrative law, economics, philosophy and historical sciences, the content of the concept of "objectivity". It is stated that the principle of objectivity in the course of operational-search activities by criminal police units consists in the everyday use by the specified subject of certain criteria, in the final form they will provide an opportunity to establish the real circumstances of the preparation or commission of a crime, persons committing illegal activities, to reveal information of interest to criminal proceedings. It is emphasized that in economics the principle of objectivity is to adequately describe the initial parameters of the employee. This is the main principle of assessment; it requires the use of scientific methods that give the maximum possible objective assessment. Principles of timely complexity and effectiveness require that the original parameters and indicators (estimates) used in the solution of a particular personnel problem, be timely and fully presented and necessarily used. It is concluded that objectivity in the field of operational search activities is a combination of such 
criteria as: impartiality; failure to take into account one's own apprehensions, thoughts, beliefs, or other factors of a particular employee when performing operational search activities on objects of operational development, objects of overlapping, silent apparatus, etc. as the main criterion for decision making; independence in decision-making from the political, social and economic situation of both their own and persons under control; management in the course of the operative-search activity solely by the law; the correlation of the actual signs of a crime in a person's actions upon management's order to prosecute such person.

Key words: objectivity, principle, operational-search activity, criminal police units.

Постановка проблеми та їі актуальність. Дедалі частіше у засобах масової інформації можна побачити чи почути про те, що працівники оперативних підрозділів $€$ не об'єктивними під час виконання своїх посадових обов'язків. Зокрема, зустрічаються поняття «не об'єктивні під час встановлення особи злочинця», «не об'єктивні під час збору доказів, відомостей», «не об'єктивні щодо обставин злочину» тощо. Водночас, аналізуючи теорію оперативно-розшукової діяльності, можна дійти висновку, що серед принципів ії здійснення до галузевих відносять саме принцип об'єктивності. 3 урахуванням вказаного постає питання щодо визначення самого поняття «об'єктивність», його критеріїв і значення під час здійснення оперативно-розшукової діяльності підрозділами кримінальної поліції.

Аналіз останніх досліджень і публікацій. Взагалі в теорії оперативно-розшукової діяльності дослідженню питань, пов'язаних із принципами оперативно-розшукової діяльності, було присвячено значну кількість праць. Зокрема, на рівні монографічних досліджень окреслена проблематика була частково досліджена останніми роками в монографії М.С. Цуцкірідзе на тему: «Кримінально-процесуальна діяльність слідчого: теоретичні, правові та праксеологічні засади», кандидатській дисертації Д.М. Ценова на тему: «Оперативно-розшукове забезпечення підрозділами кримінальної поліції досудового розслідування злочинів корисливо-насильницького спрямування» та на рівні методико-практичного матеріалу М.М. Перепелицею в лекції на тему: «Поняття, завдання, принципи та правова основа оперативно-розшукової діяльності». Водночас слід зазначити, що увагу було приділено й вивченню кожного окремого принципу оперативно-розшукової діяльності, однак, аналізуючи вказані наукові праці, а також наукові розробки інших фахівців у сфері оперативно-розшукової діяльності, слід дійти висновку, що безпосередньо питання реалізації принципу об'єктивності під час оперативно-розшукової діяльності не досліджувалося.

Метою статті $\epsilon$ визначення поняття «принцип об'єктивності під час оперативно-розшукової діяльності підрозділів кримінальної поліції».

Виклад основного матеріалу. Взагалі об'єктивність - філософське поняття, що означає характеристику предмета, зміст знання чи спосіб існування (дійсності), яка полягає в їхній незалежності від людської свідомості (суб'єкта пізнання).

Розрізняють такі форми об'єктивності:

- онтологічну,

- гносеологічну,

- методологічну,

- професійну [1].
Водночас, аналізуючи різну публіцистичну та наукову літературу, можна побачити, що “об'єктивність» як певний критерій діяльності розглядається у багатьох науках, причому доволі неоднозначно.

Так, проблема об'єктивності наукового пізнання у психологічній науці завжди була найбільш важкою і досі однозначно не вирішеною. Адже психологія здавалася багатьом особливої наукою, тому що в ній пізнавальна активність суб'єкта спрямована не на зовнішню реальність, а на самого себе, на свій внутрішній світ. Багато психологів на цій підставі спочатку відмовлялися від визнання психології об'єктивної наукою. «Хіба можна об'єктивно вивчати суб'єктивне?» - запитували вони, маючи на увазі під суб'єктивним внутрішній світ суб'єкта, відкритий для пізнання нібито тільки йому самому і нікому іншому. У межах цієї позиції головним (а іноді навіть єдиним) методом пізнання психічних явищ проголошувався метод інтроспекції. Сумнівність цього методу давно вже озвучувалася багатьма дослідниками, наприклад, І.М. Сеченовим, який вважав, що, якби психологія дійсно володіла таким особливим «знаряддям» для «безпосереднього» пізнання психіки, вона давно випередила б у своєму розвитку інші науки.

Інші автори, як, скажімо, представники виниклого на початку XX Ст. у США біхевіоризму, наполягали на тому, що психологія все-таки повинна бути об'єктивною наукою. Але, оскільки, як вважали біхевіористи, свідомість (яка внутрішньо спостерігається) не можна вивчати об'єктивно, вони пропонували інший вихід: потрібно вивчати об'єктивно те, що дійсно об'єктивне (це означає, на їхню думку, ззовні) і може спостерігатися. Біхевіористи побачили таку реальність у поведінці суб'єкта і проголосили предметом психології не свідомість (яке розуміли принципово так само, як і в попередній їм психології), а поведінку.

У вітчизняній психології виник інший погляд на вирішення цієї проблеми: можна і треба вивчати об'єктивно саме свідомість, психіку, але тоді слід змінити погляд на їхню суб'єктивність. Так виникло уявлення про те, що термін «суб'єктивне» може мати (і мав в історії психології) три різні значення:

1. У першому сенсі суб'єктивне трактується як повна протилежність об'єктивній реальності, як світ «безпосереднього» досвіду, який повинен вивчатися зовсім іншими методами, ніж об'єктивна реальність.

2. У другому сенсі суб'єктивне означає спотворене, упереджене, неповне і т. п. У цьому відношенні воно протиставляється об'єктивному як істинному, неупередженому, повному. Упередженість може бути вивчена й об'єктивно, як це показав, наприклад, Л.С. Виготський, котрий зауважив: «Призначення психіки зовсім не в тому, щоб відображати дійсність дзеркально, а в тому, щоб спотворювати дійсність на користь організму» [2]. Так що суб'єктивність психіки означає, отже, зумовленість психіки насамперед потребами (мотивами) ії суб'єкта й адекватність психічного відображення саме тою мірою, якою воно допомагає суб'єкту зорієнтуватися у світі та діяти в ньому. Сучасна психологія мотивації доводить можливість науково-об'єктивного вивчення специфіки суб'єктивного спотворення дійсності суб'єктом залежно від конкретних мотивів його діяльності.

3. У третьому значенні «суб'єктивний» - це те, що належить суб'єкту, виконує конкретні функції в його життєдіяльності, має цілком об'єктивні форми існування і тому може бути вивчене різними об'єктивними 
методами (для вираження цього сенсу більше підходить термін «суб'єктний»). Як довели прихильники діяльнісного підходу у психології (С.Л. Рубінштейн, А.Н. Леонтьєв, А.Р. Лурія, П.Я. Гальперин, Д.Б. Ельконин та ін.), існування психічних процесів у різних суб'єктивних (у першому сенсі) формах $\epsilon$ вторинним явищем, тоді як вихідним і основним способом їхнього буття $\epsilon$ об' $є$ ктивне існування в різних формах предметно-практичної діяльності суб'єкта [2].

Водночас в історичній науці принцип об'єктивності розглядається як:

1) установка на отримання знання, адекватного історичній дійсності;

2) важливий орієнтир, покликаний звести до мінімуму суперечності між історичним фактом і його численними інтерпретаціями;

3) установка на науковість історичного дослідження й істинність історичних знань. Нині склалися різні уявлення про те, що таке об'єктивність і в чому суть принципу об'єктивності в історичному пізнанні.

Об'єктивність історичного знання полягає не в тому, що вони адекватні історичній реальності, а в тому, що в цих моделях презентується історична реальність. Така презентація забезпечується науковістю історичного дослідження і прагненням історика до істини, що має когерентний характер. В умовах методологічного плюралізму, пов'язаного зі співіснуванням у когнітивних практиках різних моделей історичного дослідження, принцип об'єктивності трактується по-різному, а саме як установка на: а) адекватність, б) істинність, в) науковість, г) достовірність [3].

Що ж стосується філософського підходу, то за ним принцип об'єктивності розглядається як об'єкт пізнання, що існує поза і незалежно від суб' єкта і самого процесу пізнання. 3 цього принципу випливає методологічна вимога - будь-який об'єкт дослідження треба приймати таким, яким він $\epsilon$. Отриманий результат дослідження повинен виключати будь-який прояв суб'єктивності, щоб не видати бажане за дійсне.

Суб'єкт повинен утримуватися від своїх пристрастей на адресу об'єкта пізнання. Одночасно суб'єкт пізнання не повинен на догоду якимось міркуванням відступати від отриманої істини щодо об'єкта пізнання.

Крім того, принцип об'єктивності вимагає фіксувати не тільки форму об'єкта, але і його можливі проекції в інших ситуаціях. Тільки таким чином можна забезпечити чистоту гносеологічного відносини в системі «Суб'єКт - об'єКТ» [4].

В економічних науках принцип об'єктивності полягає в адекватному описі вихідних параметрів працівника. Це головний принцип оцінки, він зумовлює обов'язковість використання наукових методів, що дають максимально можливу об'єктивну оцінку. Принципи своєчасної комплексності та результативності вимагають того, щоб вихідні параметри і показники (оцінки), які використовуються при вирішенні того чи іншого кадрового завдання, були своєчасно і в повному обсязі представлені й обов'язково використані [5].

Аналізуючи такі підходи, можна дійти висновку, що спільним для здійснення певної діяльності конкретним суб'єктом без урахування особистісних, суб'єктивних, обставин та ознак, тобто у реальній площині, $\epsilon$ максимально адекватне та повне їх відображення/використання.
У свою чергу, у сфері оперативно-розшукової діяльності також $є$ декілька підходів до поняття змісту принципу об'єктивності.

Так, наприклад, М.Л. Грібов, аналізуючи загальне питання щодо принципів діяльності підрозділів оперативної служби МВС України, визначає: дослідження сутності таких принципів ОРД, як «об'єКтивність», «об'єКтивна істина», «об'єктивність і повнота», «усебічність, повнота й об'єктивність» дає підстави для висновку, що науковці мають на увазі одне і те саме. У діяльності підрозділів оперативної служби, на думку М.Л. Грібова, слід виокремлювати принципи повноти й об'єктивності, який $\epsilon$ правилом забезпечення максимально якісного рівня виконання завдань гласних оперативних підрозділів на проведення ОР3, а також правилом неупередженого ставлення до об'єктів цих заходів, недопущення обвинувального чи виправдального нахилу при оформленні документів за їх результатами [7].

Проводячи надалі більш глибокі дослідження саме вказаного принципу, М.Л. Грібов вказує, що неправильно використовувати в ОРД назву принципу «об'єктивної істини», тож схиляється до думки, що його доцільно іменувати як принцип усебічності, повноти й об'єктивності. До його змісту вказаний вчений включає і правило незалежності в отриманні та поданні отриманої інформації, що виокремлюється Р.А. Халілевом як самостійний загальний принцип ОРД. Окреслене він пояснює тим, що підрозділи оперативної служби не ведуть оперативно-розшукових справ, а тому не висувають оперативно-розшукових версій, тож щодо ïх діяльності доцільно говорити лише про повноту й об'єктивність. Повнота забезпечується максимально якісним рівнем відпрацюванням завдань гласних оперативних підрозділів на ОРЗ. Об'єктивність - неупередженим ставленням до об'єктів цих заходів, недопущенням обвинувального чи виправдувального нахилу при оформленні документів за їх результатами. Принцип повноти й об'єктивності в діяльності ПОС $є$ правилом забезпечення максимально якісного рівня виконання завдань гласних оперативних підрозділів на OP3, а також правилом неупередженого ставлення до об'єктів цих заходів, недопущення обвинувального чи виправдувального нахилу при оформленні документів за їх результатами [7].

У свою чергу, Б.А. Керницький стверджує: принцип об'єктивності означає, що будь-які відомості, які стосуються агентурної роботи, не повинні прийматися на віру і підлягають всебічній і скрупульозній перевірці, і лише після підтвердження їх достовірності можуть бути використані у правоохоронній діяльності ОВС. Свою думку він обґрунтовує тим, що у практичній діяльності значна кількість агентурних відомостей (82\%) оформлюється як агентурна записка. Зазначене призводить до того, що іноді оперативні працівники викладають агентурну інформацію так, як їм бажано, чи навіть фальсифікують надходження оперативної інформації [8, с. 83].

Водночас слід проаналізувати чинне законодавство, зокрема Кримінальний процесуальний кодекс і Закон України «Про оперативно-розшукову діяльність» [9; 10]. Так, чинним законодавством не тлумачиться вказаний принцип, однак фактичне його розуміння можливо отримати шляхом аналізу окремих положень. Зокрема, передбачені у ст. 1 Закону України «Про оперативно-розшукову діяльність» завдання ОРД (пошук і фіксація 
фактичних даних про протиправні діяння окремих осіб і груп, відповідальність за які передбачена Кримінальним кодексом України, розвідувально-підривну діяльність спеціальних служб іноземних держав та організацій з метою припинення правопорушень та в інтересах кримінального судочинства, а також отримання інформації в інтересах безпеки громадян, суспільства і держави) фактично закріплюють, що оперативні працівники, не враховуючи суб'єктивні ознаки, повинні здійснювати свої обов'язки (наприклад, особа, котра вчиняє злочин, $є$ знайомою, симпатизує за зовнішністю тощо) [10]. У ст. 41 КПК України працівникам оперативних підрозділів вказується на обов'язковість виконання доручень слідчого, а, враховуючи положення ст. 2 КПК (забезпечення швидкого, повного та неупередженого розслідування і судового розгляду з тим, щоб кожний, хто вчинив кримінальне правопорушення, був притягнутий до відповідальності в міру своєї вини, жоден невинуватий не був обвинувачений або засуджений, жодна особа не була піддана необґрунтованому процесуальному примусу і щоб до кожного учасника кримінального провадження була застосована належна правова процедура) [9], можна говорити про непряме визначення принципу об'єктивності.

Враховуючи вказане, можна дійти висновку, що значення принципу об'єктивності під час здійснення оперативно-розшукової діяльності полягає у досягненні мети кримінального провадження й оперативно-розшукової діяльності шляхом відсторонення від суб'єктивних чинників і керування виключно нормами права.

Тобто об'єктивність у сфері оперативно-розшукової діяльності полягає в сукупності таких критеріїв, як:

- неупередженість;

- не враховування власних уподобань, думок, віросповідання або інших факторів конкретного працівника під час здійснення оперативно-розшукової діяльності щодо об'єктів оперативної розробки, об'єктів перекриття, негласного апарату тощо як основного критерію прийняття рішення;

- незалежність у прийнятті рішень від політико-соціального й економічного становища як власного, так i осіб - об'єктів контролю;

- керування під час здійснення оперативно-розшукової діяльності виключно нормами закону;

- співвідношення фактичних ознак злочину в діях особи на наказу керівництва щодо притягнення такої особи до кримінальної відповідальності.

\section{Організаційно-правові аспекти} досудового слідства

Висновки. Отже, враховуючи вищевикладене, можна дійти висновку, що принцип об'єктивності під час здійснення оперативно-розшукової діяльності підрозділами кримінальної поліції полягає в повсякденному використанні означеним суб'єктом певних критеріїв, які дадуть змогу встановити реальні обставини підготовки чи вчинення злочину, осіб, котрі вчиняють протиправну діяльність, виявити відомості, що становлять інтерес для кримінального провадження.

\section{Література}

1. Об'єктивність. Матеріал з Вікіпедії - вільної енциклопедіï. URL: https://uk.wikipedia.org/wiki/\%D0\%9E\%D0\% B1\%27\%D1\%94\%D0\%BA\%D1\%82\%D0\%B8\%D0\%B2\%D0\%BD\%D1\% 96\%D1\%81\%D1\%82\%D1\%8C.

2. Принцип объективности. URL: https://studfile.net/ preview/5410302/.

3. Объективности принцип. URL: http://ponjatija.ru/ node/16315.

4. Принцип объективности. URL: http://eurasialand.ru/ txt/asp/86.htm.

5. Принцип объективности. URL: https://economy-ru. info/info/107368/.

6. Грібов М.Л. Принципи діяльності підрозділів оперативної служби MBC України. URL: http: / / www.irbis-nbuv.gov.ua/cgi-bin/irbis_nbuv/ cgiirbis_64.exe? I21DBN=LINK\&P21DBN=UJRN\&Z21ID= \&S $21 R E F=10 \& S 21 C N R=20 \& S 21 S T N=1 \& S 21 \mathrm{FMT}=$ ASP_meta\&C21COM=S\&2_S21P03=FILA=\&2_S21STR= Vlduvs_2011_4_35.

7. Грібов М.Л. Принципи гуманізму, повноти та об'єктивності в діяльності підрозділів оперативної служби МВС України.

8. Керницький Б.А. Організаційно-тактичні аспекти агентурної роботи підрозділів кримінальної міліції у протидії загальнокримінальній злочинності. Одеса, 2008, 218 с.

9. Кримінальний процесуальний кодекс України від 13 квітня 2012 р. № 4651-VI (поточна редакція на підставі Закону України від 04 липня 2013 р. № 406-VII). URL: http://zakon4.rada.gov.ua/laws/show/4651-17.

10. Про оперативно-розшукову діяльність : Закон України від 18 лютого 1992 р. № 2135-XI. URL: http://zakon2.rada.gov.ua/laws/show/2135-12.

Стащак А. Ю., кандидат юридичних наук, докторант Харківського начіонального університету внутрішніх справ 